\title{
過運動発作を呈した前頭葉てんかんに対する外科治療
}

\author{
大沢 伸一郎1)2), 岩崎 真樹 ${ }^{3)}$, 高山 裕太郎 ${ }^{4)}$, 神 一敬 ${ }^{4)}$, 中里 信和 ${ }^{4)}$, 冨永 悌二 ${ }^{1)}$ \\ 1）東北大学大学院医学系研究科神経外科学分野, 2) 東北大学病院高度救命救急センター, 3）国立精神・神経医療研究セン \\ 夕一病院脳神経外科, 4) 東北大学大学院医学系研究科てんかん学分野
}

\section{Surgical Treatment of Intractable Epilepsy presenting with Hyperkinetic Seizures originating in the Frontal Lobe}

\author{
Shin-ichiro Osawa, M.D., Ph.D. ${ }^{1) 2}$, Masaki Iwasaki, M.D., Ph.D. ${ }^{3)}$, Yutaro Takayama, M.D., Ph.D. ${ }^{4)}$, \\ Kazutaka Jin, M.D., Ph.D. ${ }^{4)}$, Nobukazu Nakasato, M.D., Ph.D. ${ }^{4)}$, and Teiji Tominaga, M.D., Ph.D. ${ }^{1)}$ \\ 1) Department of Neurosurgery, Tohoku University Graduate School of Medicine, 2) Department of Critical Care and Emer- \\ gency Medicine, Tohoku University Hospital, 3) Department of Neurosurgery, National Center of Neurology and Psychiatry, \\ 4) Departments of Epileptology, Tohoku University Graduate School of Medicine
}

Hyperkinetic seizures (HKS) are characterized by complex movements involving the proximal segment of the limbs and trunk. The proximal predominance of these movements results in large movements, thus the label "hyperkinetic." Previous reports suggested the orbitofrontal and anterior cingulate cortex are associated with HKS.

We describe the two male patients with frontal lobe epilepsy who manifest HKS. Both were successfully treated by surgical resection.

The patients experienced their first seizures at eleven years old and five years old. Both cases exhibited progressive, intractable HKSs and intellectual deterioration. In both, HKS was misdiagnosed as a psychosis. At the ages of nineteen, they were evaluated by a comprehensive epilepsy monitoring unit. FLAIR MR images revealed thickened gray matter and hyperintensity of white matter at right anterior cingulate cortex in one case and that at left frontal lobe involving orbitofrontal area in the other case. Long-term video electroencephalography (EEG) showed interictal spikes in fronto-temporal area in both cases. Ictal EEG was non-localizable in the former, and attenuation in left frontal area in the latter.

The former was evaluated using intracranial EEG recording, and revealed that the anterior cingulate cortex was the seizure-onset zone. Followed focal cortical resection was performed. The latter was done the extended frontal lobectomy with preservation of the language area since functional mapping is not ideal in patients with mental retardation. Both patients emerged seizure-free.

This work underscores the importance of considering HKS, which is easily misdiagnosed as a psychiatric disorder, as a manifestation of frontal lobe epilepsy.

(Received April 23, 2018 ; accepted May 15, 2018)

Key words : epilepsy surgery, hyperkinetic seizure, orbitofrontal cortex, anterior cingulate cortex, psychiatric disorder

Jpn J Neurosurg（Tokyo）27 : 764-772, 2018

連絡先：大沢伸一郎， $=980-8574$ 仙台市青葉区星陵町 1-1 東北大学大学院医学系研究科神経外科学分野

Address reprint requests to : Shin-ichiro Osawa, M.D., Ph.D., Department of Neurosurgery, Tohoku University Graduate School of Medicine, 1-1 Seiryo-machi, Aoba-ku, Sendai-shi, Miyagi 980-8574, Japan 


\section{緒 言}

過運動発作は前頭葉てんかんに特徵的で，带状回皮質 および前頭葉眼窩皮質が症状発現に関連すると考えられ ている.

今回われわれは過運動発作を呈する難治てんかんに対 し，上記皮質領域を焦点と同定して外科的切除を行い， 良好な発作転帰を得た 2 症例を経験したので報告する。

\section{症例提示}

\section{1 症例 1}

手術時 19 歳の男性. 11 歳でてんかん発症した。当初 は就寝時に両上肢を羽ばたくように 30 秒ほど動かす発 作だったが，次第に小学校の授業中に急に走り出す，唸 り顔面蒼白となる, 両手, 体を左右に摇らし座り込むな
どより複雑な発作が数回〜数十回/日の単位で出現する ようになった。発作は夜間睡眠時に多く, 落ちつきのな さなどの行動異常を指摘され学業成績は低下した。心療 内科を経て小児科を受診し，てんかんと診断され治療が 開始された。当時のMRIを含む画像診断では無病変てん かんと判断されていた。 以後 7 年間, 計 8 剂の抗てんか ん薬調整にもかかわらず難治に経過した. 18 歳時に外科 治療適応を求め当院に紹介され, 包括的てんかん精査を 行った。長時間ビデオ脳波モニタリングでは，突然両手 を屈曲し唸り声を伴い体幹, 頭部を左右ないし前後に摇 らす過運動発作が記録された (Fig. 1A)。発作時間は 20〜 30 秒で, 発作後速やかに改善する意識減損を伴ってい た. 脳波は発作間欠時に右半球性の間欠性デル夕律動と 右前頭部棘波を認め（Fig. 1B left）, 発作時脳波で右前側 頭部のデル夕律動を認めた（Fig. 1B right）。脳磁図では 両側帯状回前部周辺に外側方向の等価電流双極子の集積
A
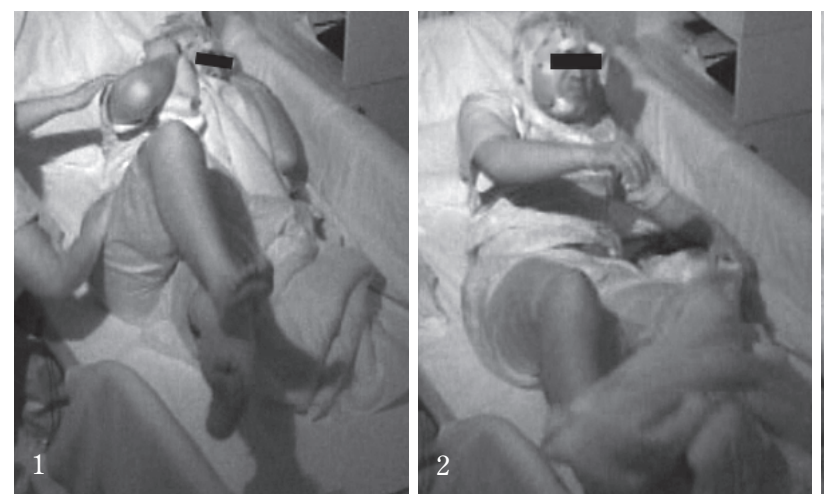
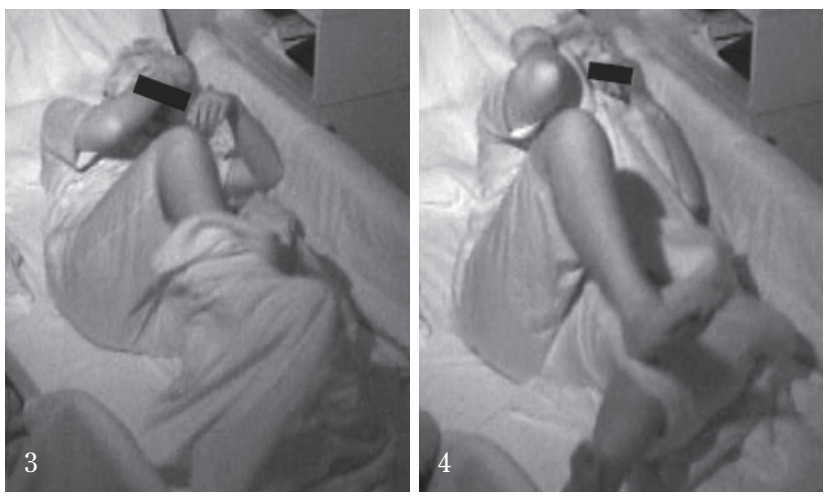

Ictal onset
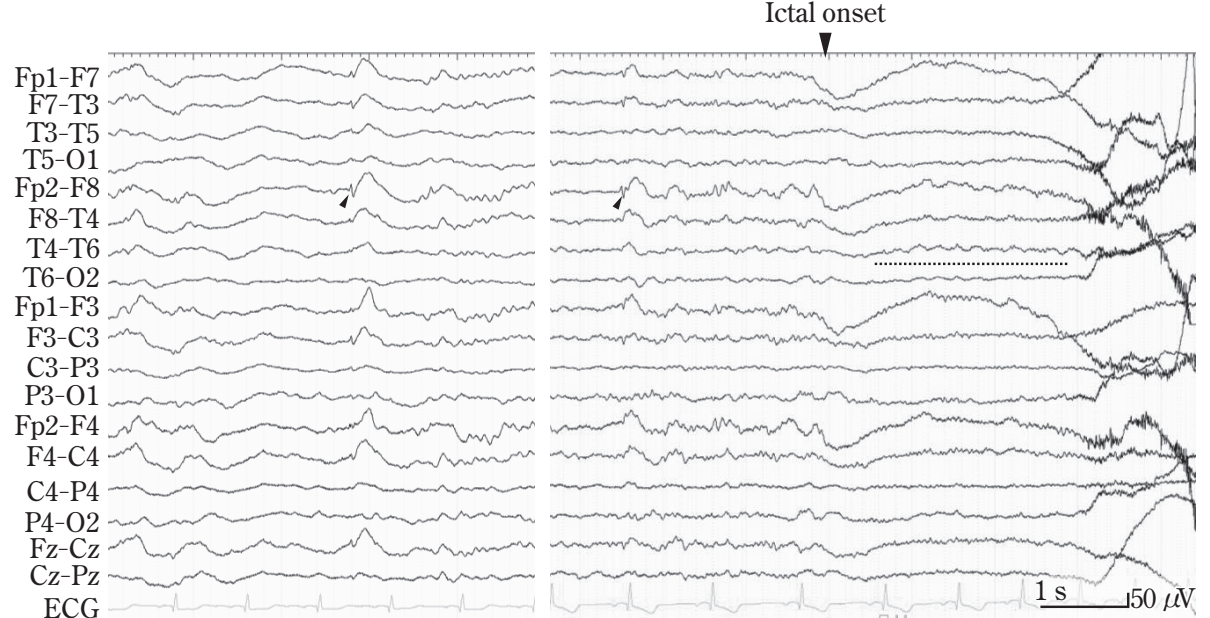

Fig. 1 Long-term video-EEG recording of the case 1

A : His seizure started with sudden arousal from sleep and involved complex movements such as a rocking trunk and swinging of the proximal limb segments with moaning. The seizures lasted $20-30$ seconds and abruptly ended.

B : Interictal spikes (arrowheads in left and right figure) were seen in the mid-frontal region, with the maximum values at the F8 electrode (left). No clear focal changes were detected, despite following delta activity at the right temporal region (dotted line) at the onset of the seizure (right). 

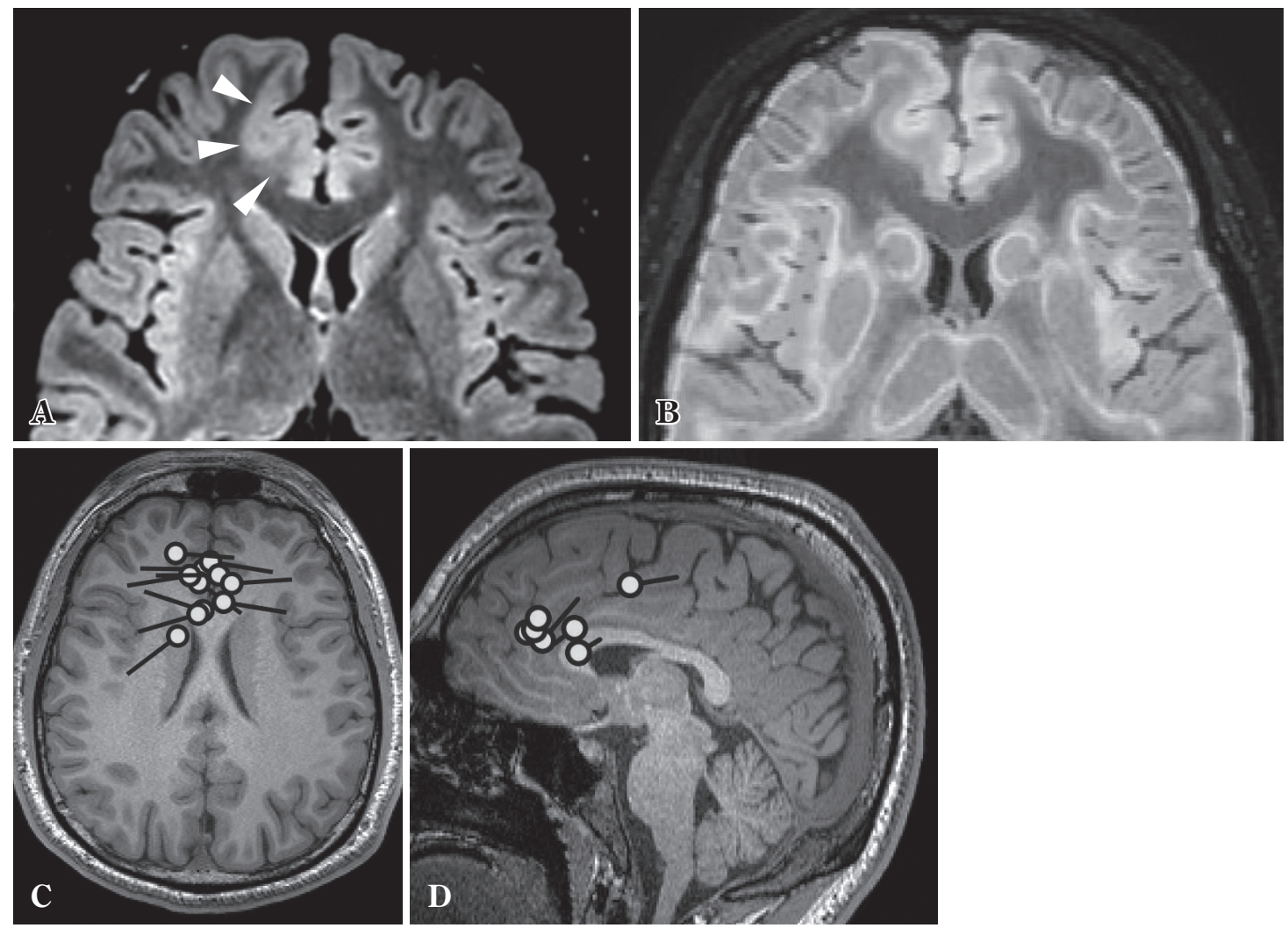

Fig. 2 A, B : Fluid-attenuated inversion recovery (FLAIR) MRI demonstrate focal hyperintensity of the white matter at the right anterior cingulated cortex (A). Fluorodeoxy-glucose positron-emission tomography (FDG-PET) revealed a focal hypometabolism in the region overlapping the lesion on MRI (B).

C, D : The computed ECD from the MEG clustered around bilateral anterior cingulate cortex.

を認めた（Fig. 2C, D). 3 T-MRI FLAIR 画像で右帯状回 前部に白質高信号および皮髄境界不明瞭化を認め, FDG-PET で同部に一致する集積低下を認めた（Fig. 2A， B)。神経心理検査ではウェクスラー成人知能検査 (WAIS)-IIIで言語性 IQ 66, 動作性 IQ 71, 総合 IQ 66 と 全般性低下を認めた。

以上より，てんかん焦点は右帯状回前部周辺に存在す るものと推定した。外科治療の適応として, 頭蓋内脳波 記録による焦点診断を経て切除術を行う方針とした.

右帯状回周辺から外側前頭葉皮質に発作起始の有無を 確認し, さらに発作症候学から予想される眼窩前頭皮質 の活動も併せて記録するため, 頭蓋内電極留置を行った (Fig. 3A). 発作時脳波では, 右前部带状回近傍より低振 幅速波で始まり周囲電極へ拡延する所見が得られた (Fig. 3B). MRI 病変に一致したてんかん焦点と判断し, 電極抜去とともに右前部帯状回の皮質切除を行い（Fig. 3C), 発作は消失した。病理は限局性皮質形成異常 type II bであった。以後 3 年 5 力月間再発なく経過している.

\section{2 症例 2}

手術時 19 歳の男性. 5 歳時に夜間全身を硬直させる発 作で発症し, 脳波で左前頭部の異常を指摘された。てん かんと診断され薬物治療を開始するも, 以後難治に経過 した. 13 歳頃から発作症状が変化し, 夜間睡眠中に四肢 を不規則にばたつかせ，体を前後左右に摇する過運動発 作が週単位で出現，その後頻度上昇し日中覚醒時も含め た毎日複数回の発作となった。計 9 郕の抗てんかん薬調 整で発作は抑制されず, 18 歳時に外科治療の適応を検討 するため，当科で包括的てんかん精査を行った。

長時間ビデオ脳波モニタリングでは睡眠中に突然両手 を屈曲, 伸展して体幹を左右, 前後に摇らす過運動発作 が記録された（Fig. 4A）。発作時間は 30〜 40 秒で，発作 後すみやかに改善する意識減損を伴っていた。発作間欠 時, 反復性に持続していた左前頭部鋭波が発作起始とと もに消失して振幅減衰を認め, 局在所見は明らかでな かった（Fig. 4B)。発作間欠時脳波の左前頭部棘波につ いて，脳磁図で左中前頭回，下前頭回，眼窩前頭皮質に 


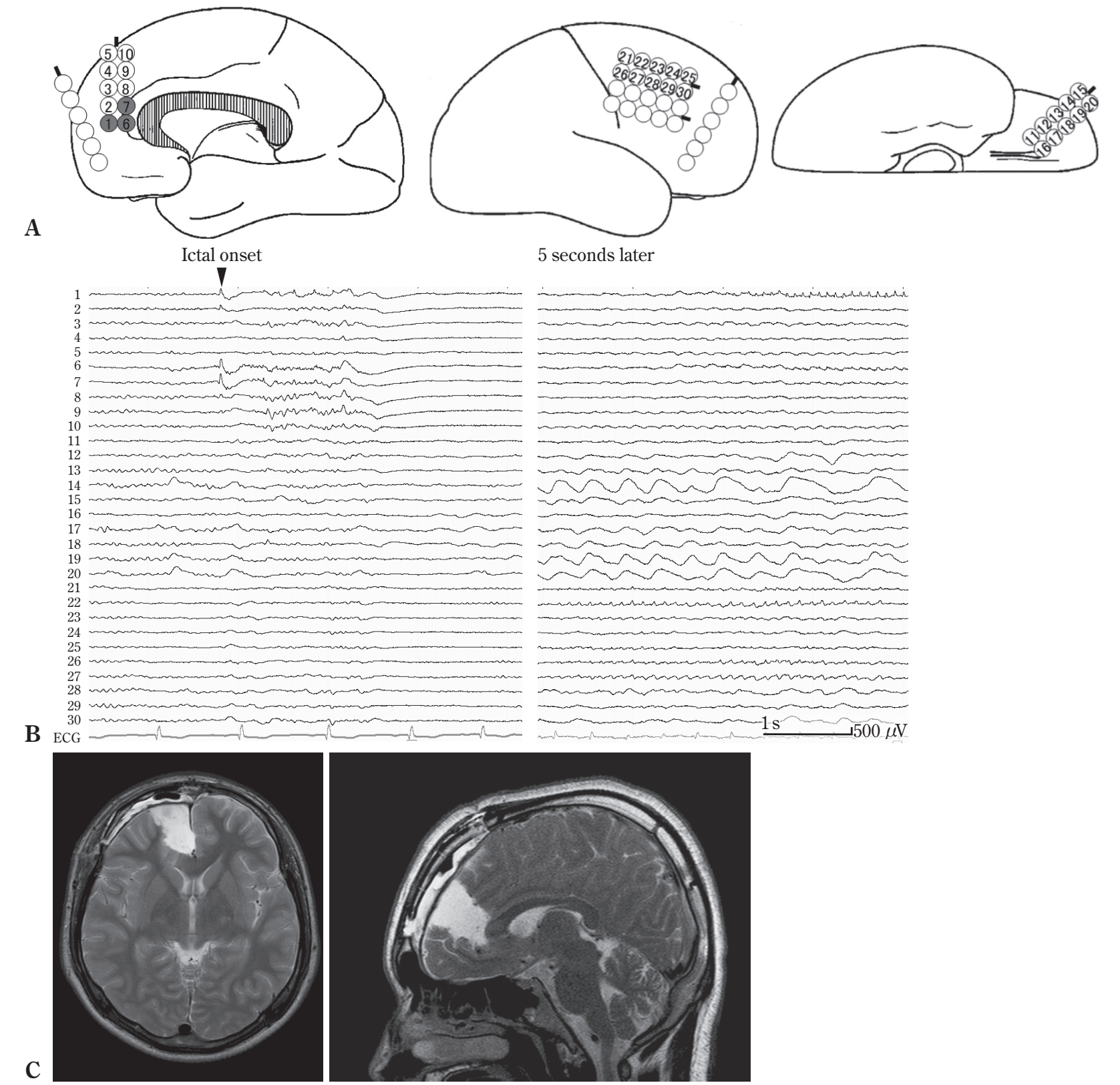

Fig. 3 A : Schematic illustrations of subdural electrode implantation in case 1. Inter-electrode distance was 1 $\mathrm{cm}$. Location of the seizure onset is shown by the filled circle.

B : Intracranial EEG was referenced to the extracranial lead. The locations of the electrodes are indicated in illustration (A). At the onset of the seizure, spikes at electrode 1, 6, and 7 followed transient beta activity, building up 7 seconds later in the surrounding electrode.

C : Postoperative T2-weighted MRI show focal resection of the medial frontal cortex, including the anterior cingulated cortex.

等価電流双極子の集積を認めた (Fig. 5E, F). 3 T-MRI FLAIR 画像で左中前頭回から下前頭回および眼窩前頭 皮質に皮骾境界不明瞭な病変を認め, FDG-PETで同部 を含む前頭葉の集積低下を認めた（Fig. 5A-D）.

神経心理検査では WAIS-IIIで VIQ 52, PIQ 48, IQ 46, ウェクスラー記憶検査 (WMS) - R は全項目で 50 以下で
あり, 中等度以上の精神発達遅滞に加え, 複数の抗てん かん薬使用による認知機能への影響があると推測した。

画像所見からてんかん焦点は眼窩前頭皮質を中心とし て一部前方言語領域に重なって存在するものと推定され た.しかし本患者は(1)発作頻度が非常に多いこと，(2)す でに精神発達遅滞が進行していることから，慢性頭蓋内 
A
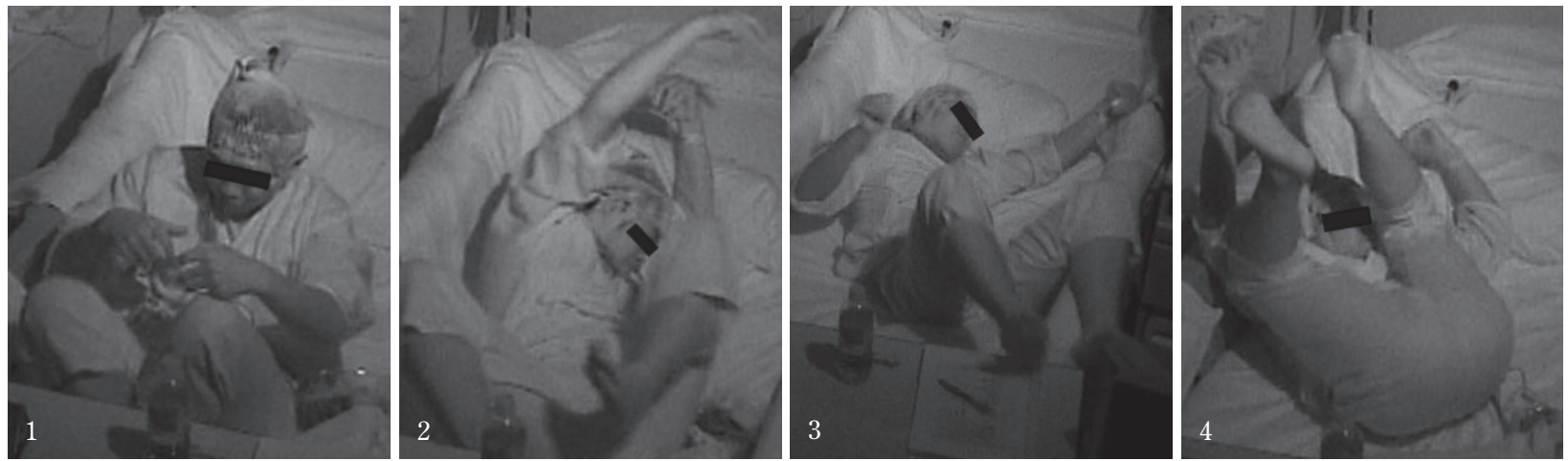

Ictal onset
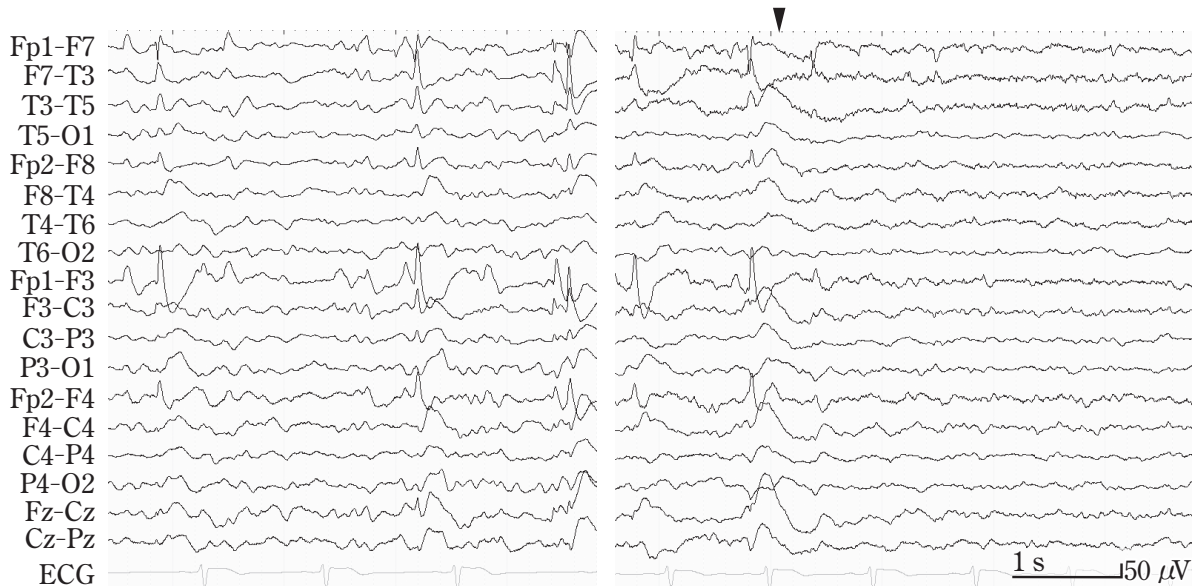

Fig. 4 Long-term video-EEG recording of the case 2

A : His seizure was very similar to the case 1 .

B : Interictal spikes were seen in the frontal region, with the maximum values at the Fp1 electrode (left). Ictal EEG showed generalized attenuation (right).

電極留置による言語野を含めた脳機能マッピングを遂行 できない可能性が高いと判断し，一期的な切除術を行う 方針とした。

手術は高次機能低下の可能性よりも発作消失・減少を 重視し，機能領域を最低限温存した拡大病変切除を計画 した。具体的には言語機能皮質である下前頭回を温存 し, 中前頭回から内側，下方にかけて眼窩前頭皮質を含 む前頭葉皮質切除を行った (Fig. 6). 術後発作は消失し, 神経学的合併症は認めなかった。病理は限局性皮質形成 異常 type IIbであった。以後 12 力月間発作再発はない.

\section{考 察}

今回われわれは過運動発作で発症した前頭葉てんかん に対し, 切除手術を行った 2 症例を報告した。

てんかんにおける過運動発作は体幹, 四肢の複雑で激 しい身振り自動症を呈する特徵的な発作症状で知られて いる ${ }^{1) 813)}$. 今回報告した 2 症例に共通する特徴は(1)発作
頻度が日単位と多い，(2)夜間睡眠時の発作が多い，(3)発 作後もうろう状態はないかきわめて短い，などが挙げら れる。これらは従来指摘されてきた前頭葉てんかんによ る過運動発作の特徴と合致しており ${ }^{13) 15)}$, 診断の助けと なった。睡眠時の発作が多い点は，近年確立されてきた 睡眠関連過運動発作てんかん（sleep-related hypermotor epilepsy：SHE）との鑑別が問題となる.SHE はほぼす べての発作が睡眠時に起こること, 発作時および発作間 欠時の脳波異常に乏しいことなどが特徵とされ，発作起 源は脳深部領域を含む前頭葉外に想定されている ${ }^{17)}$. 今 回の 2 症例はいずれも切除によって発作消失した明瞭な てんかん焦点を有しており，SHEではなかった。しかし 発作の相同性は共通の脳内基盤を推定させ，生理学的に 興味深い。過運動発作を生み出す機序については未解明 な部分が多いが, 発作時 SPECT の脳血流増加領域から, 前頭葉に加え辺縁系構造や脳幹などの複数領域が関与し て発作形成に至ると推測されている ${ }^{9)}$.

過運動発作の症状発現領域は帯状回前部，眼窩前頭皮 

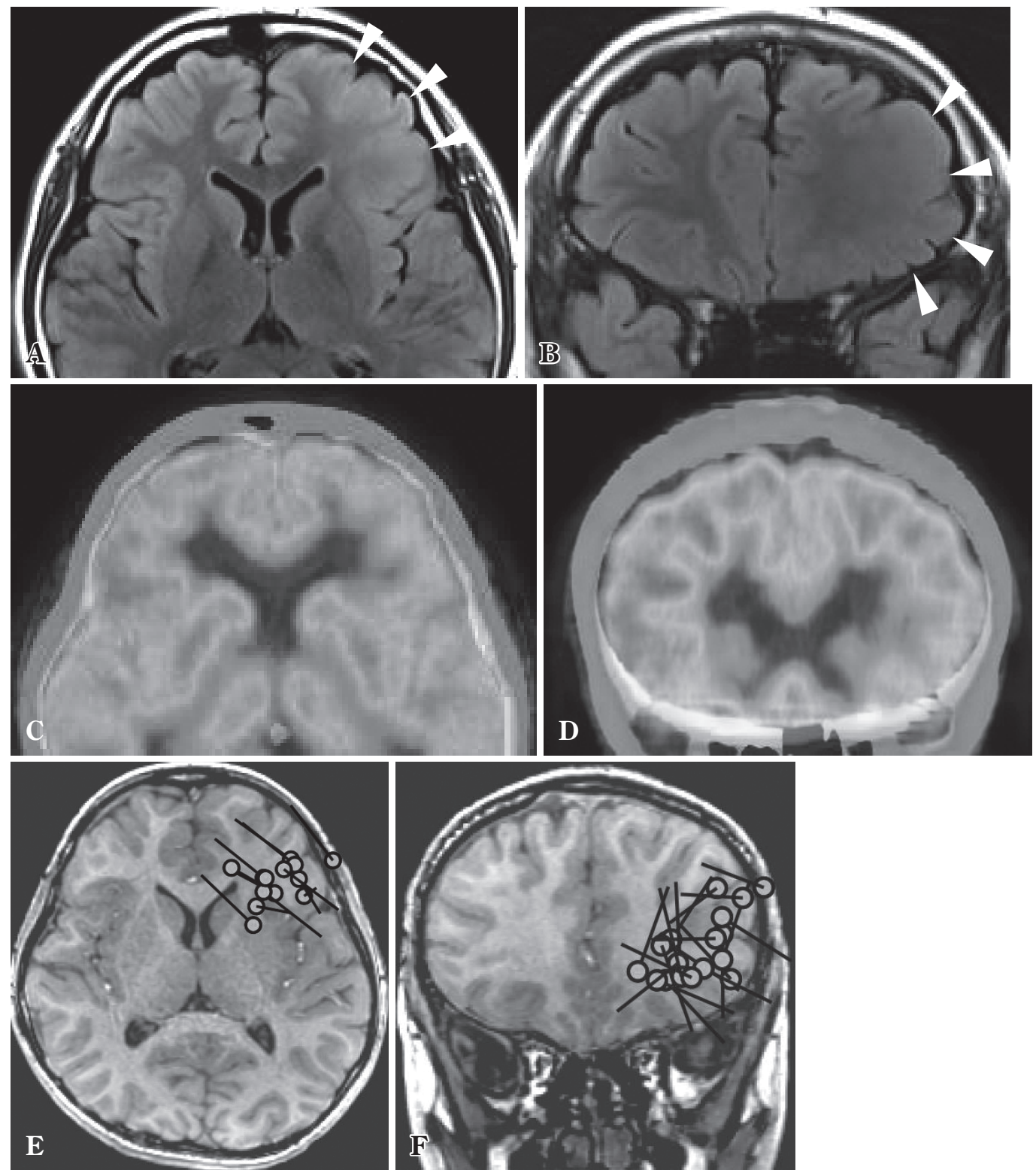

Fig. 5 A-D : FLAIR MRI demonstrate regional white matter hyperintensities at the middleto-inferior frontal gyrus and orbitofrontal field in the left hemisphere (A, B arrowheads). FDG-PET demonstrated regional hypometabolism that involves the lesion in MRI ( C, D).

E-F : The computed ECD from the MEG clustered lateral and basal frontal area.

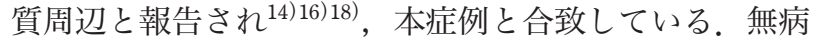
変てんかんであっても，前兆のない過運動発作，睡眠関 連の過運動発作は眼窩前頭皮質のてんかんを疑うべきと される ${ }^{1)}$ 。しかし発作起始が典型的な眼窩前頭皮質，带 状回前部でない頭頂葉5) 10)11)，側頭葉 ${ }^{12)}{ }^{19)}$ ，島回 ${ }^{27)}$ に焦 点を認めた症例も報告されており，正確な診断には脳機 能局在，ネットワークを考慮した臨床データの総合的判 断が必要であろう。

前頭葉てんかんの手術成績について, Elsharkawy ら ${ }^{3)}$ は手術後発作転帰について頭蓋内電極留置を必要とした
症例や術後てんかん性異常波残存が不良因子であり，術 前 MRI の明瞭病変, 病変に一致したてんかん性異常波, もしくは若年症例が転帰良好と報告している。これらの 因子からは「術前に明確に切除領域を決定できること， 機能マッピングが不要で病変を含んだ拡大切除が可能な 患者に早期外科治療を行うこと」が転帰良好を示唆する と考元られ，眼窩前頭皮質周辺のてんかん外科治療成績 が良好であるという事実はそれを支持している1).

症例 2 では言語機能領域を含むてんかん原性領域が想 定され，同領域の切除にあたっては頭蓋内電極記録を経 

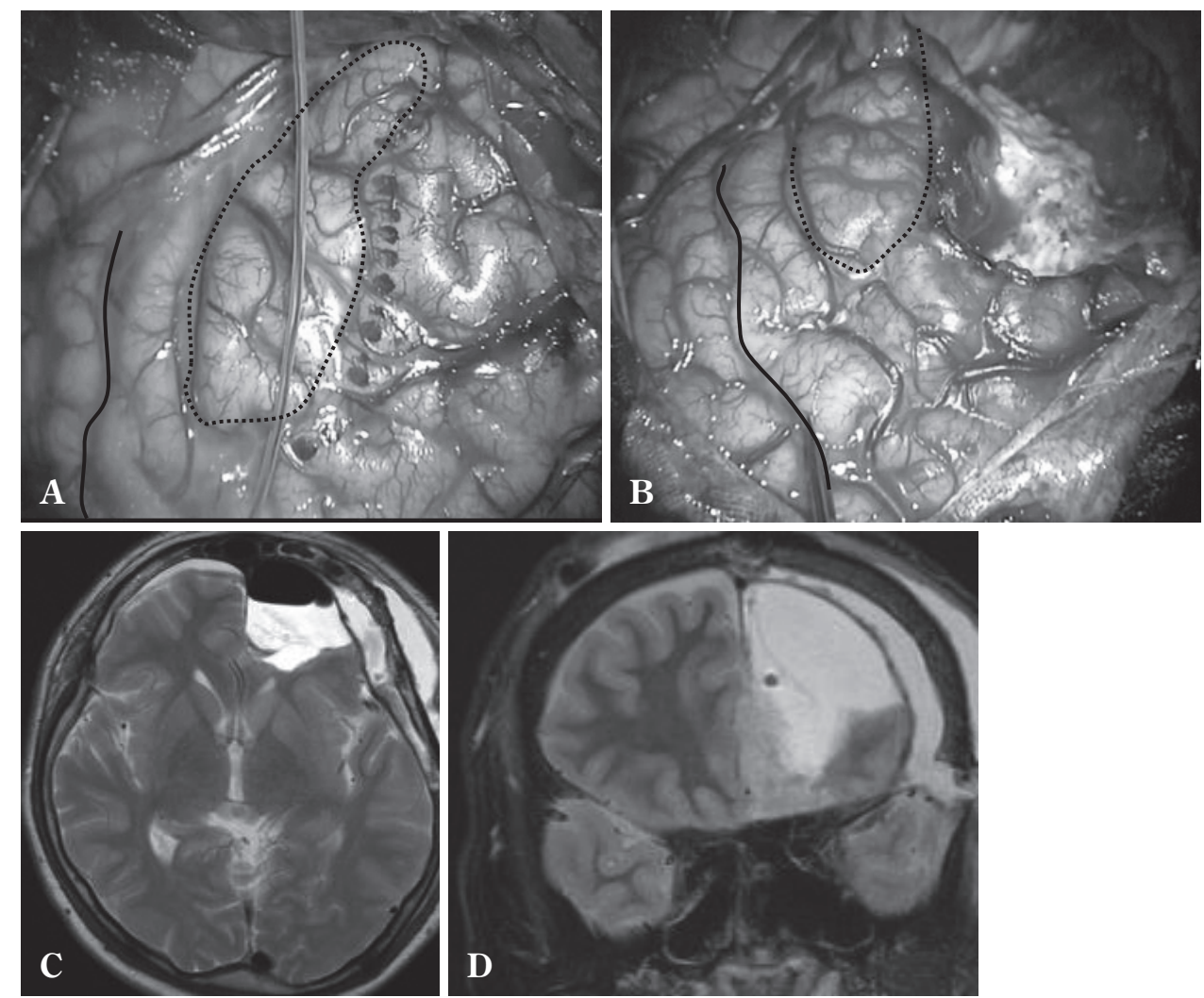

Fig. 6 A, B : Intraoperative microsurgical view shows the pre-(A) and post- $-(\mathbf{B})$ procedure views of left frontal lobectomy. Resection area was marked from the anatomical location of the central sulcus (filled line) and inferior frontal gyrus (dotted circle) without functional mapping (A).

C, D : Postoperative T2-weighted MRI show frontal lobectomy with preservation of the left inferior frontal gyrus.

た二期的手術も考慮された。しかし本患者の発作頻度は 数十回/日ときわめて高く，また大きな体幹運動を伴い 安全性のリスクがあること, さらに高次機能低下があり 頭蓋内電極留置や覚醒下タスクには耐え難いと判断し, 総合的に一期的切除の方針とした。同様の議論は他の機 能領域にもあてはまり, 外科手術として妥当なリスク管 理を選択する必要がある。

てんかんの過運動発作は精神疾患と誤診されやすく, 症例 1 はてんかんと診断されるまでに心療内科受診を経 ている，長時間ビデオ脳波モニタリングを含むてんかん 精査を行えば, 本発作が真のてんかん発作か否かを鑑別 するのに困難を伴うことは少ない.この問題はてんかん 発作の知識啓発に関わる問題であり, 一般医家への浸透 が必要である。また過運動発作は発作頻度が高く精神症 状を随伴することもあり, 手術治療により発作消失を得 られるメリットは大きいと思われる。

本症例 1 は初療時に画像上無病変とされていたが，そ の後 3 T-MRIで異常を指摘された。てんかん患者の画像
診断は他の脳神経外科疾患に比して異常所見が軽微であ ることが多く，臨床情報と併せて高磁場 MRI で診断する ことが重要とされている(4)6). また診断技術の進歩に伴 い治療適応は変化していくため, 一度外科治療困難と判 断されても，その後数年で再評価を行えば診断が覆るこ とがあるのは慢性疾患であるてんかんに特徵的である.

\section{おわりに}

前部带状回および前頭葉眼窩皮質を焦点とする, 過運 動発作を呈した前頭葉てんかんの 2 症例を報告した。い ずれもてんかん精査によるてんかん焦点の特定に加え, 疾患もしくは患者特性に基づいた外科適応の議論が必要 であった。過運動発作を呈するてんかんは精神症状や睡 眠時行動異常と誤診されやすく, 診断にあたつては留意 すべきである。 


\section{謝 辞}

The authors would like to thank Enago (www.enago.jp) for the English language review.

\section{COIについて}

著者のうち神 一敬は，自己申告による COI 報告書を日本 脳神経外科コングレス事務局に提出しています。その他の著 者全員は, 日本脳神経外科学会への COI 自己申告を完了して います。いずれも本論文に関して開示すべき COI はありませ ん.

\section{文 献}

1) Chibane IS, Boucher O, Dubeau F, Tran TPY, Mohamed I, McLachlan R, Sadler RM, Desbiens R, Carmant L, Nguyen DK : Orbitofrontal epilepsy : Case series and review of literature. Epilepsy Behav $\quad \mathbf{7 6}: 32-38,2017$.

2) Dobesberger J, Ortler M, Unterberger I, Walser G, Falkenstetter T, Bodner T, Benke T, Bale R, Fiegele T, Donnemiller E, Gotwald T, Trinka E : Successful surgical treatment of insular epilepsy with nocturnal hypermotor seizures. Epilepsia 49: 159-162, 2008.

3) Elsharkawy AE, Alabbasi AH, Pannek H, Schulz R, Hoppe M, Pahs G, Nayel M, Issa A, Ebner A : Outcome of Frontal Lobe Epilepsy Surgery in Adults. Epilepsy Res 81:97106, 2008.

4) Focke NK, Symms MR, Burdett JL, Duncan JS : Voxel-based analysis of whole brain FLAIR at $3 \mathrm{~T}$ detects focal cortical dysplasia. Epilepsia 49: 786-793, 2008.

5) Gibbs SA, Figorilli M, Casaceli G, Proserpio P, Nobili L : Sleep related hypermotor seizures with a right parietal onset. J Clin Sleep Med 11: 953-955, 2015.

6) Hashiguchi K, Morioka T, Murakami N, Suzuki S, Hiwatashi A, Yoshiura T, Sasaki T : Utility of 3-T FLAIR and 3D short tau inversion recovery MR imaging in the preoperative diagnosis of hippocampal sclerosis : Direct comparison with 1.5-T FLAIR MR imaging. Epilepsia 51: 1820-1828, 2010.

7) Kaido T, Otsuki T, Nakama H, Kaneko Y : Hypermotor seizure arising from insular cortex. Epilepsia $\quad 47: 1587-1588$, 2006.

8) Lüders H, Acharya J, Baumgartner C, Benbadis S, Bleasel A, Burgess R, Dinner DS, Ebner A, Foldvary N, Geller E, Hamer H, Holthausen H, Kotagal P, Morris H, Meencke HJ,
Noachtar S, Rosenow F, Sakamoto A, Steinhoff BJ, Tuxhorn I, Wyllie E : Semiological seizure classification. Epilepsia 39: 1006-1013, 1998.

9) Masuda H, Shariff E, Tohyama J, Murakami H, Kameyama $\mathrm{S}$ : Clinical patterns and pathophysiology of hypermotor seizures : an ictal SPECT study. Epileptic Disord 14:32-40, 2012.

10) Montavont A, Kahane P, Catenoix H, Ostrowsky-Coste K, Isnard J, Guénot M, Rheims S, Ryvlin P: Hypermotor seizures in lateral and mesial parietal epilepsy. Epilepsy Behav 28: 408-412, 2013.

11) Nishibayashi H, Ogura M, Taguchi M, Miki J, Uematsu Y, Itakura $\mathrm{T}$ : Nondominant parietotemporal cortical dysplasia manifesting as hypermotor seizures. Epilepsy Behav 14: 691-695, 2009.

12) Nobili L, Cossu M, Mai R, Tassi L, Cardinale F, Castana L, Citterio A, Sartori I, Lo Russo G, Francione S : Sleeprelated hyperkinetic seizures of temporal lobe origin. Neurology 62: 482-485, 2004.

13) O'Brien TJ, Mosewich RK, Britton JW, Cascino GD, So EL : History and seizure semiology in distinguishing frontal lobe seizures and temporal lobe seizures. Epilepsy Res $\mathbf{8 2}$ : 177-182, 2008.

14) Provini F, Plazzi G, Tinuper P, Vandi S, Lugaresi E, Montagna $\mathrm{P}$ : Nocturnal frontal lobe epilepsy. A clinical and polygraphic overview of 100 consecutive cases. Brain 122:10171031, 1999.

15) Rheims S, Ryvlin P, Scherer C, Minotti L, Hoffmann D, Guenot $\mathrm{M}$, Mauguière F, Benabid AL, Kahane $\mathrm{P}$ : Analysis of clinical patterns and underlying epileptogenic zones of hypermotor seizures. Epilepsia $\quad 49:$ 2030-2040, 2008.

16) San Pedro EC, Mountz JM, Ojha B, Khan AA, Liu HG, Kuzniecky RI : Anterior cingulated gyrus epilepsy: The role of ictal rCBF SPECT in seizure localization. Epilepsia 41: 594-600, 2000 .

17) Tao Y, Guojun Z, Yuping W, Lixin C, Wei D, Yongjie L : Surgical treatment of patients with drug-resistant hypermotor seizures. Epilepsia 51:2124-2130, 2010.

18) Tinuper P, Bisulli F : From nocturnal frontal lobe epilepsy to Sleep-Related Hypermotor Epilepsy : A 35-year diagnostic challenge. Seizure 44:87-92, 2017.

19) Yu T, Zhang G, Wang Y, Cai L, Zhou X, Du W, Li Y : Surgical treatment of hypermotor seizures originating from the temporal lobe. Seizure $\quad 22: 862-866,2013$. 
過運動発作を呈した前頭葉てんかんに対する外科治療

大沢伸一郎 岩崎 真樹 高山裕太郎 神 一敬 中里 信和 冨永 悌二

過運動発作を呈する前頭葉てんかんに対し, 外科的切除を行った 2 例を報告する.

てんかん発症は 5 歳, 11 歳で手術年齢はともに 19 歳であった. 発作はいずれも夜間睡眠時に多く, 突然うなり声を伴い, 体幹, 四肢を前後に摇する 30 秒前後の発作であった. MRI で帯状回前部もし くは眼窩前頭皮質に皮髄境界不明瞭部分を認め, FDG-PET で同部の代謝低下を認めた. 1例は頭蓋内 脳波記録を経て皮質切除を行い, もう 1 例は頭蓋内脳波記録を省略して言語機能領域を温存した前頭 葉切除を行った. ともに発作は消失し, 病理は皮質形成異常であった.

過運動発作を呈するてんかんは精神疾患と誤診されやすく，診断にあたり留意すべきである.

脳外誌 $27: 764-772,2018$

\section{Editorial Comment}

\section{過運動発作を呈する難治性てんかんに対する手術}

過運動発作は四肢・体幹の複雑で激しい身振り自 動症や非対称性の強直発作やジストニアを呈し，奇 声, 感情的表情の激しい表出後, 発作後意識回復が 早いという特徴をもつ。

これらの特徵から, 精神症状や心因性発作と誤 解・誤診されることがある。 2017 年の国際抗てんか ん連盟の発作型分類では hypermotor seizure から hyperkinetic seizure に変更されている. 発作は数分 以内で, 夜間特に non-REM 睡眠期に多く, 発作起

\section{札幌医科大学医学部脳神経外科 三國信啓}

源は前頭葉内側が多いが頭皮上脳波では明らかでは ない場合もある。本論文の 2 症例では, 発作症状と 脳波所見, および画像診断が一致しており, 薬剤難 治性てんかんの外科適応としてふさわしい. 前頭葉 てんかんや皮質形成異常を疑うてんかん外科手術で は基本的に硬膜下電極留置が望ましく, 留置範囲が 重要である。また, 症例 2 のように留置困難例での 摘出範囲決定の理論についても十分な議論が必要と なる。 